\title{
SOME IMPORTANT CONTRIBUTIONS TO BRAZILIAN MINERALOGY
}

Paulo Cesar Pereira das Neves

Laboratório de Geologia e Mineralogia, Curso de Química Industrial

Universidade Luterana do Brasil

Canoas, RS, BRASIL

usppd@vahoo.com.br

Lavinel G. Ionescu

Scienco Scientific Consulting Services, Viamão, RS, BRASIL

and

Sarmisegetuza Research Group, Santa Fe, New Mexico, USA

lavinel.g.ionescu@gmail.com

\begin{abstract}
The purpose of this article is to highlight the major contributions to the development of Brazilian Mineralogy from pre-colonial times up to the present. A list is presented including the major figures that played an important role in the development of mineralogy in Brazil during the last five hundred years.

KEY WORDS: History of Mineralogy in Brazil, Brazilian Minerals

\section{RESUMO}

O presente artigo salienta as contribuições mais importantes para o desenvolvimento da mineralogia no Brasil do período pré-colonial até a presente data. É apresentado um elenco que inclui as pessoas que tiveram um papel de destaque no desenvolvimento da mineralogia no Brasil nos últimos quinhentos anos.
\end{abstract}

PALAVRAS CHAVE: História da Mineralogia no Brasil, Minerais do Brasil

\section{INTRODUCTION}

Brazil is well known for its mineralogical diversity. Approximately $18 \%$ of the mineralogical species known to exist in our Planet are present in Brazil. ${ }^{1-2}$ In order reach the present level of knowledge and development the contributions 
of a large number of persons was necessary. This includes the native Indian population before the discovery of our country by the Portuguese in 1500 to the first historians, scouts, explorers, merchants, miners, collectors, travelers and scientists. All of them had a high interest in our minerals and the many applications for which they served. ${ }^{1-2}$

The purpose of this work is to pay a fast homage to these people, give a short biography and point out some of their deeds and accomplishments.

1. Pêro de Magalhães Gândavo (born in Braga, 1540 and died in Braga in 1580) (Figure 1). He was the first Portuguese historian to describe expeditions in the Brazilian Highlands (Sertão) and mentioned the occurrence of native gold. His main explorations were mainly limited to the coastal region of Brazil, from Olinda ,Pernambuco to São Vicente, São Paulo. ${ }^{2-4}$

2. Gabriel Soares de Souza (born in Ribatejo, about 1540 and died at the headwaters of Paraguaçu River, Bahia in 1591 (Figure 1). He was a Portuguese historian and farmer, author of the treatise Tratado Descritivo do Brasil (1587) and made the first inferences about the occurrence of gold, iron, copper, emerald amethyst and garmet in the Brazilian Sertão, in parts of land that are today part of the state of Bahia. ${ }^{2-4}$

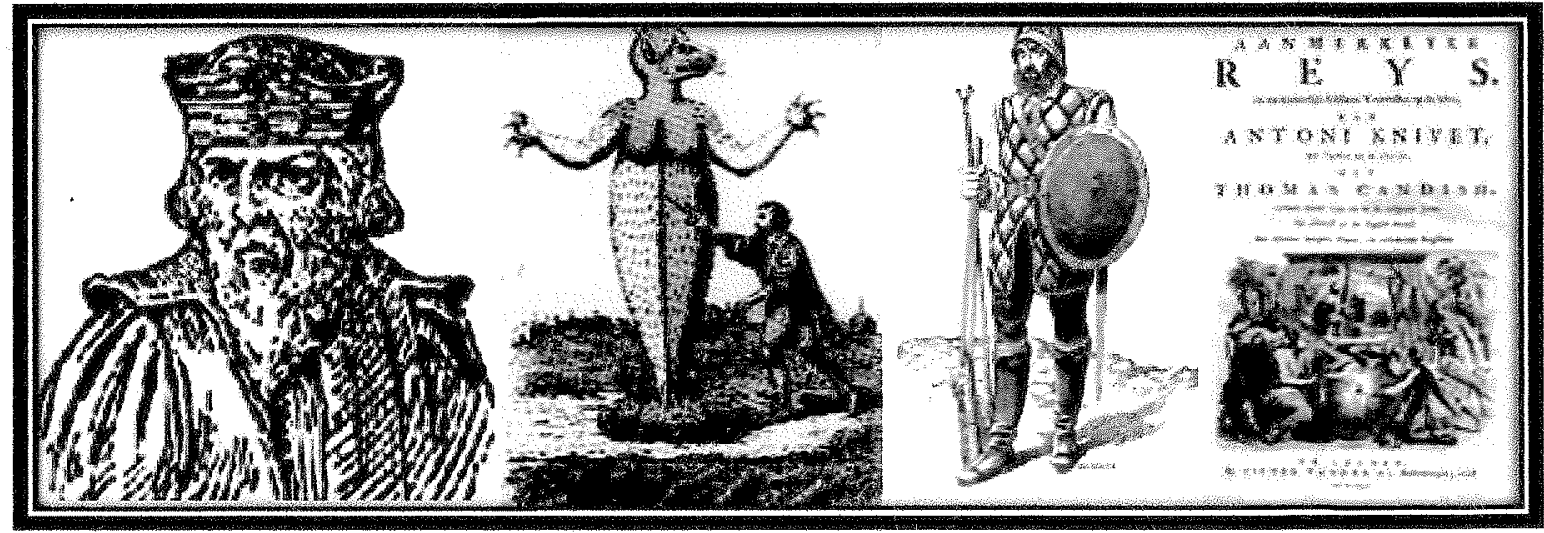

Figure 1 - Pêro Magalhães Gândavo ${ }^{9}$; Gabriel Soares de Souza ${ }^{10}$; Afonso Sardinha "the OIdhest"11; frontispíece of Anthony Knivet's book ${ }^{12}$; 


\section{SOUTHERN BRAZILIAN JOURNAL OF CHEMISTRY SOUTH. BRAZ. J. CHEM., Vol. 22,No. 22,2014}

\section{P.C.P. Neves and L.G. Ionescu}

3. Afonso Sardinha, "O Velho" was born in Portugal (date unknown) and died in 1616 in Fazenda Jaraguá, São Paulo. (Figure 1). He was a Portuguese scout and explorer, Indian hunter and perhaps the first to traffic slaves from Angola to Brazil. He discovered native gold in 1580 in Ribeirão Itaí, Pico do Jaraguă in São Paulo. He is generally considered the father of iron smelting and metallurgy in Brazil. In 1591, after the discovery of magnetite iron deposits in Ipanema near Sorocaba, together with his son, Afonso Sardinha "o Filho",who died in 1604, he established the first iron smelter in Brazil. ${ }^{2-4}$

4. Anthony Knivet (born about 1560 and died probably in 1649) was a British adventurer who lived on the Coast of Santos (region of Ithabela and and Rio Sapucai) together with the Indians and wrote a book about his strange misfortunes (Figure 1) where he relates his passage through Brazil. He found in abandoned Indian huts fishing weights that were made of gold and adornments made of emerald and possibly diamond. ${ }^{2}$

$17^{\text {th }}$ and $18^{\text {th }}$ CENTURIES - SLAVE WORK IN MIINING

5. During the $17^{\text {th }}$ century scouts and explorers fimally discovered gold on a large seale in Brazill. During this century and the subsequent times up to 1888 when slavery was abolished the African Negro performed horrible forced labor in Brazilian mines. A large number of slaves were the victims of umhealthy work conditions, exhaustion, drowning, burying amd many types of accidents ${ }^{8}$ (Figure 2). 
SOUTHERN BRAZILIAN JOURNAL OF CHEMISTRY

SOUTH. BRAZ. J. CHEM., Vol. 22,No. 22,2014

82

Important Contribution to Brazilian Mineralogy

$18^{\text {th }}$ AND $19^{\text {th }}$ CENTURIES, THE EMPIRE AND THE FIRST SCIENTISTS

6. Abraham Gottlob Werner (born in Ozieczinica in 1749 and died in Dresden in 1817) (Figure 2). He was a German geologist and emeritus professor of geology and mineralogy of the Academy of Mineralogy of Freiberg, Baden-Württenberg. In 1789 , together with another German geologist, Dietrich Ludwig Karsten, determined the first type mineral from Brazil, chrysoberyl, $\left(\mathrm{BeAl}_{2} \mathrm{O}_{4}\right)$, an oxide, found in alluvions of the region of Aracuai in Minas Gerais. ${ }^{2-4}$

7. Dietrich Ludwig Gustav Karsten (born in Bützow in $\mathbf{1 7 6 8}$ and died in Berlin in 1810) (Figure 2). He was a German mineralogist of the University of Berlin that determined with A. G. Wermer in 1789 the first type mineral from from Brazil ( chrysoberyl).

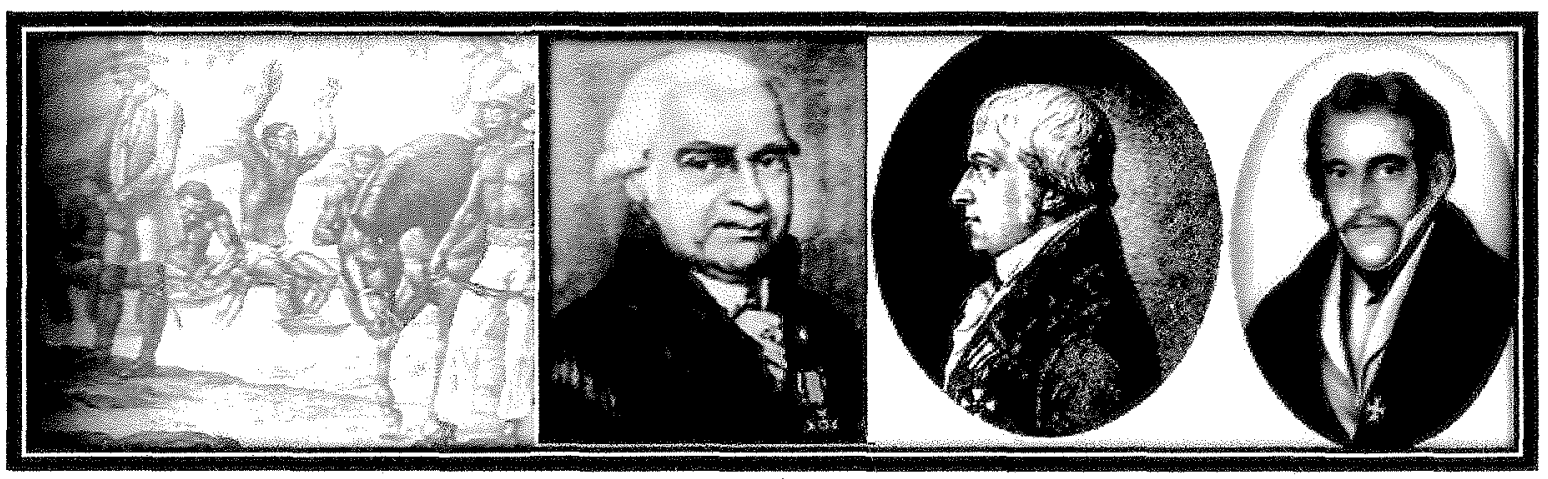

Figure 2 - Slaves in a Mine ${ }^{9}$; Abraham Gottlob Werner ${ }^{7}$; Dietrich Ludwig Güstav Karsten ${ }^{12}$; Wilhelm Ludwig von Eschwege ${ }^{2}$. 
SOUTH. BRA2. J. CHEM., Vol.22, No. 22, 2014

P.C.P. Neves and L.G. Ionescu

8. Wilhelm Ludwig von Eschwege (born in Hesse an der Aisch in 1781 and died in Kessel-Wolfsanger in 1855. (Figure 2). He was a German geologist and mining engineer who occupied the position of Director of the Real Gabinete de Mineralogia do Brasil in 1810. He founded the iron smelter in Congonhas do Campo, Minas Gerais and began its industrial operation in 1811. During his stay in Brazil (1809-1821) he gathered a large mineralogical collection that can be seen in the Museum of the Technical University of Clausthal, Germany. ${ }^{2}$

9. Johann Baptist Ritter von Spix (born in Höchstadt an der Aisch in 1781 and died in Munich in 1826 (Figure 3). He was a German naturalist who together with Karl Friedrich von Martins described the presence of topaz $\left(\mathrm{Al}_{2} \mathrm{SiO}_{4}(\mathrm{~F}, \mathrm{OH})_{2}\right)$ (a variety of imperial topaz) in Vila Rica (Ouro Preto). The two of them were also the first scientists to visit the iron meteorite (Octaedrito D) Bendegó, found in Monte Santo (present day municipality of Uauá) in the Sertão of Bahia in 1784. 2,4

10. José Bonifácio de Andrada e Silva (borr in Santos in 1793 and died in Niterói im 1838 (Figure 3 and Figure 3a). He is considered the "Father of Brazilian Mimeralogy" and was a motable statesman, chemical engineer and chemist.

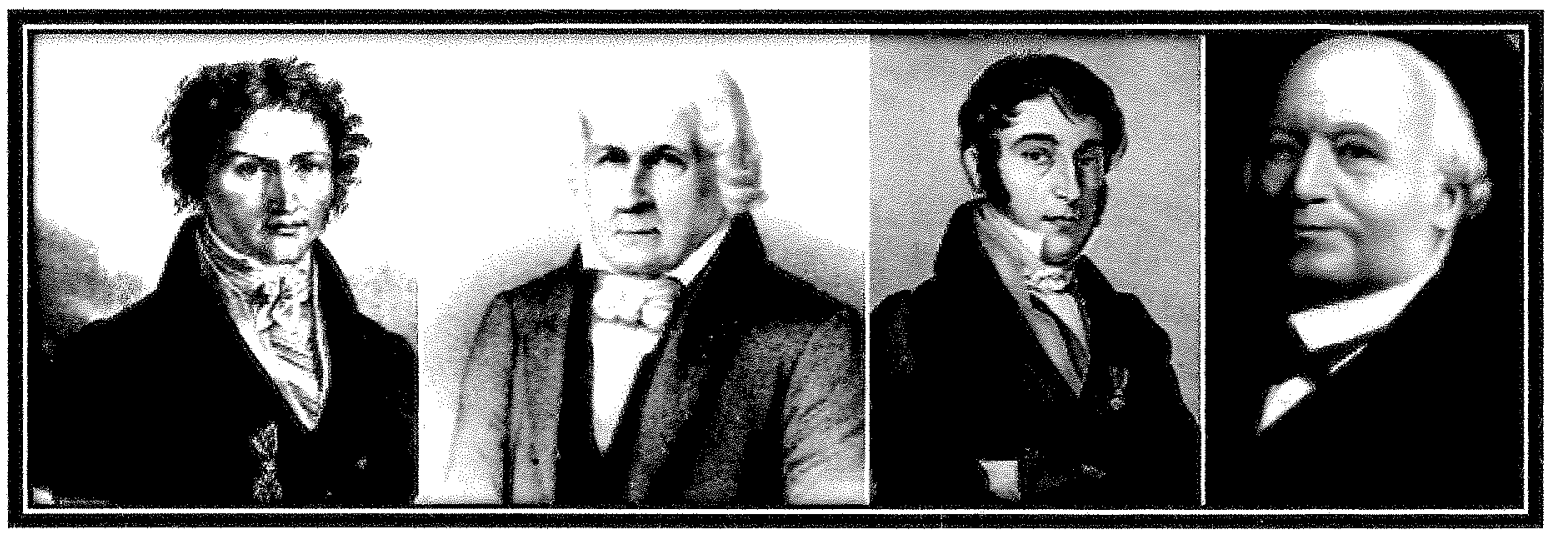

Figure 3 - Johann Baptist Ritter von Spix ${ }^{14}$; José Bonifácio de Andrada e Silva ${ }^{15}$; Karl Friederich von Martius ${ }^{16}$; Augustin Alexis Damour ${ }^{2}$. 


\section{SOUTHERN BRAZILIAN JOURNAL OF CHEMISTRY}

SOUTH. BRAZ. J. CHEM., Vol. 22,No. 22,2014

\section{Important Contributions to Brazilian Mineralogy}

84

He studied and was a professor at the University of Coimbra, Portugal before being called back to Brazil to take care of state affairs and govern the country. He was the first Brazilian scientist to describe a mineral species, petalite, a phyllosilicate with the formula $\mathrm{LiAlSi}_{4} \mathrm{O}_{10}$ occuring in a granitic pegmatite from the mines of Uto, Sodermanland, Sweden in 1800. While still in Sweden, he described three other minerals: spodumene $\left(\mathrm{LiAlSi}_{2} \mathrm{O}_{6}\right)$, cryolite $\left(\mathrm{Na}_{3} \mathrm{AlF}_{6}\right)$ and scapolite (a group of minerals that constitute a solid solution between marialite $\left(\mathrm{NaAl}_{3} \mathrm{Si}_{9} \mathrm{O}_{24} \mathrm{Cl}\right)$ and meionite $\left(\mathrm{Na}_{4} \mathrm{Al}_{6} \mathrm{Si}_{6} \mathrm{O}_{24} \mathrm{CO}_{3}\right)$.

The mineral andradite, a nesosilicate ; with the formula $\mathrm{Ca}_{3} \mathrm{Fe}^{3+}{ }_{2}\left(\mathrm{SiO}_{4}\right)_{3}$ was named in his honor by the notable American mineralogist James Dwight Dana in 1868.

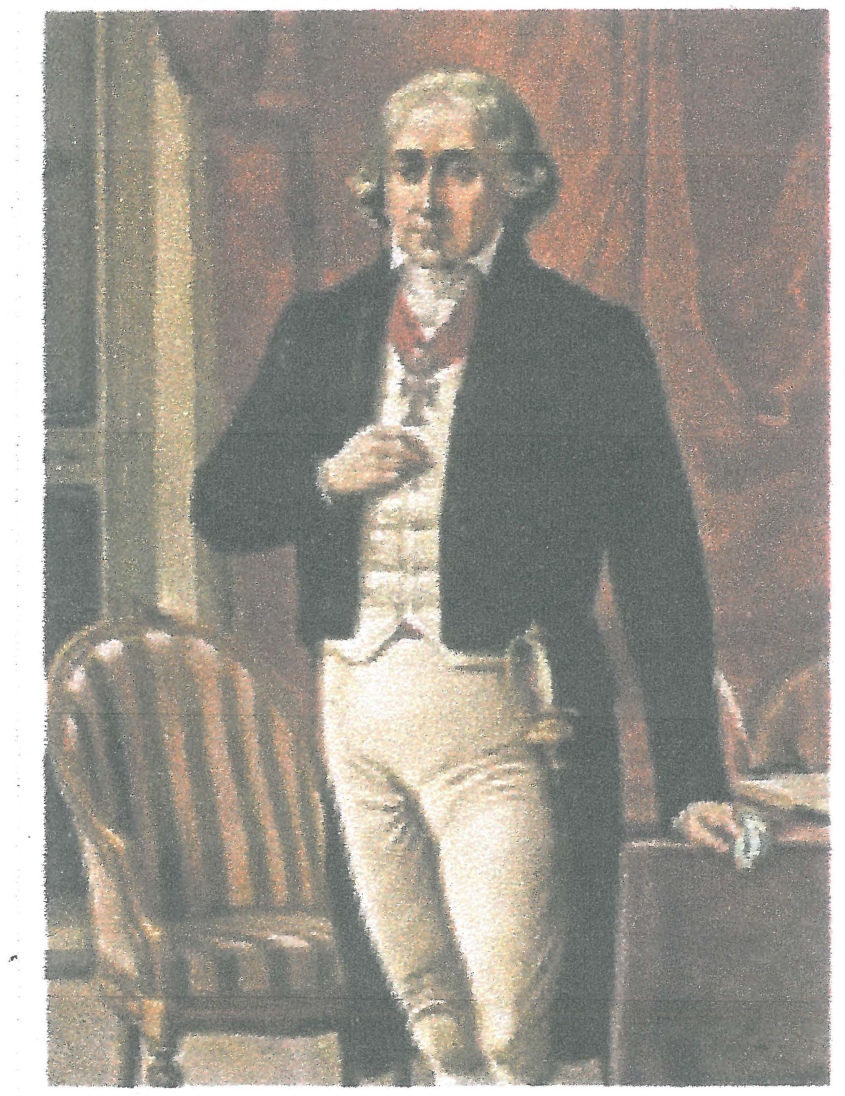

Figure 3a. José Bonifácio de Andrada e Silva (1763-1838) 
SOUTH. BRAZ. J. CHEM., Vol. 22, No. 22, 2014

P.C.P. Neves and L.G. Ionescu

José Bonifácio did most of his scientific work in Europe before returning to Brazil, where he was mainly preoccupied with the government of the country. During his stay in Europe he studied, worked and collaborated with many well known and famous scientists of the time. He also traveled widely.

Among the scholars he knew we cite the Italians Domenico Vandelli and Alessandro Giuseppe Antonio Anastasio Volta; the Frenchmen Antoine François De Fourcroy, Jean-Pierre François Guillot Duhamed and René Just Haìy; the Austrian Friedrich Mohs; the Germans Abraham Gottlob Werner, Friedrich Heinrich Alexander von Humboldt (Barom von Humboldt), Wilhem von Esclswege and Christian Leopold von Buch; the Swedes Johann Gottlieb Gahm, Carl Axel Arrhenius and Peter Jacob Hjelm; the Dane Peter Christian Abilgaard and the Spaniard Andrés Manuel Del Rio who was Professor at the School of Mines in in Mexico City and discovered the element vanadium in 1801.

José Bonifácio de Andrada was a member of the Academy of Freiberg, Bavaria, Germany. ${ }^{2,4}$ Whether or not he collaborated with W. von Eschwege and F. H. Alexander von Humboldt is doubtful for they may have not been present in Freiberg when José Bonifácio was there. 5

11.Karl Friedrich von Martins (borm in Erlangen in 1794 and died in Munich in 1862) (Figure 3). He was a German naturalist who together with Johanm Baptist Ritter von Spix described the presence of topaz (imperial topaz) in Vila Rica (Ouro Preto), Minas Gerais. The two of them were also the first scientists to visit the iron meteorite Bendegó in Bahia in $1784^{2,4,6}$ 


\section{SOUTHERN BRAZILIAN JOURNAL OF CHEMISTRY}

SOUTH. BRAZ. J. CHEM. , Vol. 22, No. 22, 2014

$19^{\text {th }}$ AND PART OF THE $20^{\text {th }}$ CENTURY - THE EMPIRE

12. Augustin Alexis Damour (Born in Paris in 1808 and died in Paris, 1902)

(Figure 3). He was a French mineralogist and diplomat who discovered in 1884 the type mineral from Brazil, goyazite, a phosphate ${ }^{2}$ with the formula $\left(\mathrm{SrAl}_{3}\left(\mathrm{PO}_{3,5}\left(\mathrm{OH}_{0,5}(\mathrm{OH})_{6}\right)\right.\right.$.

13. Claude Henri Gorceix (Born in Saint Denis dês Murs in 1842 and died in the same place in 1919 (Figure 4). He was a French mathematician and physicist who founded the School of Mines in Ouro Preto, MinasGerais in 1876. At the present it is the Universidade Federal de Ouro Preto (UFOP). At the School of Mines Gorceix was Professor of Mineralogy, Geology and Chemistry. His research activities dealt with native gold, diamond, topaz, iron and rare earth elements. In 1906, the type mineral from Brazil, gorceixita, a phosphate, was named in his honor, $\left(\mathrm{BaAl}_{3}\left(\mathrm{PO}_{3,5}(\mathrm{OH})_{0,5}\right)_{2}(\mathrm{OH})_{6}\right.$. In 1973 his mortal remains were brought from France to Brazil and were buried at the School of Mines in Ouro Preto, where there is also a statue in his honor.

14. Orville Adelbert Derby (Born in Kellogsville, New York, USA in 1851 and died in ? Rio de Janeiro in 1915) (Figure 4). He was an American geographer and geologist that became a Brazilian citizen. He did pioneering geological studies in the Amazon. In 1907 he founded and became the first Director of the Geological and Mineralogical Service of Brazil . His research dealt with gold, diamond and manganese. In 1895 the Brazil type mimeral derbyilite was named 
SOUTH. BRAZ. J. CHEM., Vol. 22, No. 22, 2014

\section{P.C. Neves and L.G. Ionescu}

in his honor. It is an antimony mineral, $\mathrm{Fe}^{3+}{ }_{4} \mathrm{Ti}_{3} \mathrm{Sb}^{4+} \mathrm{O}_{13}(\mathrm{OH})$. He apparently committed suicide because he became disappointed with the attention that his work received from Brazilian authorities.

15. Joaquim Cândido da Costa e Silva (Born in Conceição do Mato Dentro, Minas Gerais in 1852 and died in Belo Horizonte, Minas Gerais in 1919). (Figurere 4). He was a Brazilian mining engineer that occupied the positions of Director and Professor at the School of Mines in Ouro Preto. He studied the mineralogy of bismuth in Minas Gerais and the deposits of lime on the island of Fermando de Noronha in Pernambuco. He was a member of the Geology and Mineralogy Societies of Paris and Berlin and of the Imperial Society of Mineralogy of Saint Petersburg in Russia. The type mineral from Brazil, senaite, an oxide, $\left(\mathrm{Pb}(\mathrm{Ti}, \mathrm{Fe}, \mathrm{Mn})_{21} \mathrm{O}_{38}\right.$, was named in his honor in 1898.

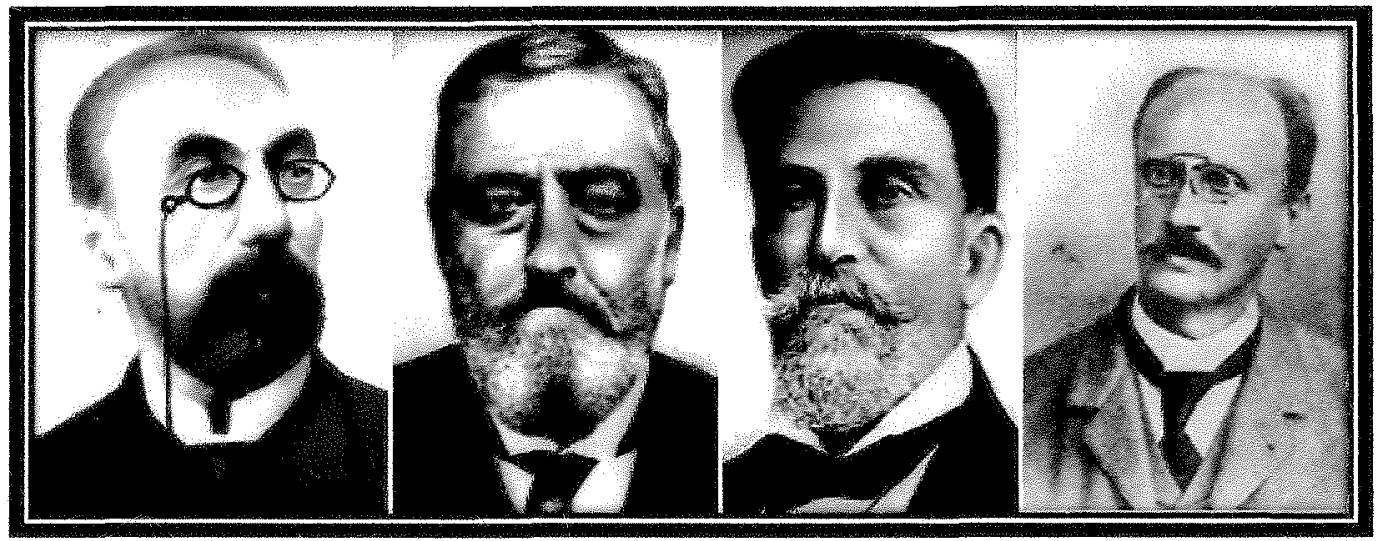

Figure 4 - Claude-Henri Gorceix ${ }^{2}$; Orville Adelbert Derby ${ }^{2}$; Joaquim Cândido da Costa Sena ${ }^{2}$; Eugen Hussak ${ }^{2}$.

16. Eugen Hussak (Born in Austria in 1856 and died in Caldas, Goiás in 1911)

(Figure 4). He was an Austrian mineralogist that together with George Thurland 
SOUTH. BRAZ. J. CHEM., Vol. 22, No.22, 2014

Important Contributions to Brazilian Mineralogy

88

Prior, a British mineralogist, described in 1895 the following type minerals from

Brazil : derbylite $\left(\mathrm{Fe}^{3+}{ }_{4} \mathrm{Ti}_{3} \mathrm{Sb}^{3+} \mathrm{O}_{33}(\mathrm{OH})\right.$ : triphuyite $\left(\mathrm{Fe}^{3+} \mathrm{Sb}^{5+} \mathrm{O}_{4}\right)$, senaite

$\left(\mathrm{Pb}(\mathrm{Ti}, \mathrm{Fé}, \mathrm{Mn})_{21} \mathrm{O}_{38}\right.$ and florencite $-(\mathrm{Ce})\left(\mathrm{CeAl}_{3}\left(\mathrm{PO}_{4}\right)_{2}\left(\mathrm{OH}, \mathrm{H}_{2} \mathrm{O}\right)_{6}{ }^{2,4}\right.$

Later on, in 1906 Hussak described the type mineral from Brazil gorceixite

$\left(\mathrm{BaAl}_{3}\left[\mathrm{PO}_{3}(\mathrm{O}, \mathrm{OH})\right]_{2}(\mathrm{OH})_{6}\right.$ in homage to the French scientist Claude-Henry

Gorceix, founder of the School of Mines of Ouro Preto.

17. George Thurland Prior (Born in Oxford in 1862 and died in 1936 in an unknown place (Figure 5). He was a British mineralogist who together with Eugen Hussak described in 1895 the type minerals from Brazil derbylite, triphuyite, florencite-(Ce) and senaite.

18. Dom Pedro Augusto Luis Maria Miguel Gabriel Rafael Gonzaga de Saxe-Coburgo-Gotha e Bragança (Born in Rio de Janeiro in 1866 and died in Viena in 1934) (Figure 5). He was nephew of Dom Pedro II, Emperor of Brazil and was a civil engineer by training. He was also well versed in mineralogy, gathered a large mineral collection and published various works on the subject. ${ }^{2}$

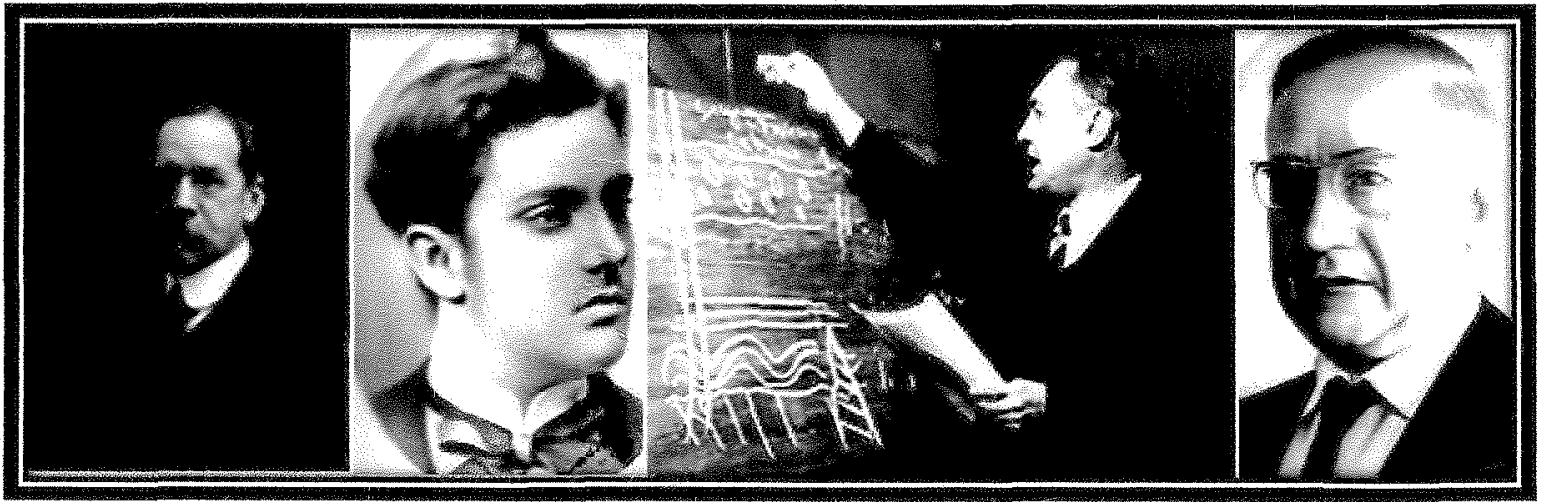

Figure 5 - George Thurland Prior ${ }^{17}$; Dom Pedro Augusto Luis Maria Miguel Gabriel Rafael Gonzaga de Saxe-Coburgo-Gotha e Bragança²; Djalma Guimarães ${ }^{18}$; Viktor Leiz ${ }^{2}$. 
SOUTH. BRAZ. J. CHEM., Vol. 22, No. 22, 2014

P.C. Neves and L.G. Honescu

19. Djalma Guimarães (Born in Santa Luzia das Velhas, Minas Gerais in 1894 and passed away in Belo Horizonte, Minas Gerais in 1973 (Figure 5). He was a notable Brazilian civil, mining and metallurgical engineer and a very prominent geoscientist. In 1925 he determined the occurrence in Brazil of the mineral arrojadite, presently arrojadite-( $\left.\mathrm{KNa}),(\mathrm{KFe})(\mathrm{KNa}) \mathrm{Fe}^{2+}\left(\mathrm{Ca}, \mathrm{Na}_{2}\right) \mathrm{Fe}^{2+}\right)_{13}\left(\mathrm{Al}\left(\mathrm{PO}_{4}\right)_{11}\right.$ $\left(\mathrm{PO}_{3} \mathrm{OH}\right)(\mathrm{OH})_{2}$ that is of the phosphate group. The name arrojadite was given in honor of the Brazilian geologist Miguel Arrojado Ribeiro Lisboa. Djalma Guimarães also determined the following Brazilian minerals: eschwegeite (presently polycrasium-Y(YCa, $\left.\mathrm{Ce}, \mathrm{U}, \mathrm{Th})(\mathrm{Ti}, \mathrm{NbTa})_{2} \mathrm{O}_{6}\right)$ and penmaite (variety

of giannetite, that is symonymous with hainite $\left(\mathrm{Na}_{2} \mathrm{Ca} 4(\mathrm{REE}) \mathrm{Ti}\left(\mathrm{Si}_{2} \mathrm{O}_{7}\right)_{2} \mathrm{OF}_{3}\right)^{2,4,6}$. In 1964 Djalma Guimarães published the monumental work Geologia do Brasil.

\section{REST OF THE $20^{\text {th }}$ CENTURY - THE REPUBLIC- PRESENT TIME}

20. Viktor Leiz ( Born in Germany in 1904 and died in São Paulo in 1983) (Figure 5). He was a German geologist and mineralogist that came to Brazil and became one of the most respected Brazilian scientists. While Director of the National Museum of Rio de Janeiro he organized the mineral collection. In 1949 he accepted the position of Professor of the Faculty of Philosophy, Sciences and Letters of the University of São Paulo, played an important role in the development of geosciences in Brazil and was the first chairman of the Geology Department.

VISIT OUR SITE: http:/www.sbjchem.he.com.br 
SOUTH. BRAZ. J. CHEM., Vol. 22, No. 22, 2014

Important Contributions to Brazilian Mineralogy

90

In 1958 he received the José Bonifácio de Andrada e Silva Gold Medal, the highest prize awarded in geology in Brazil. He was a member of the Brazilian Academy of Sciences, Academy of Sciences of the State of São Paulo and CNPq- National Brazilian Research Council. His most important legacy was the work Geologia Geral, the first genuinely Brazilian textbook of geology that stimulated and guided many generations of geologists for several decades. ${ }^{2,20}$

21. Rui Ribeiro Franco ( Born in São José do Rio Pardo, São Paulo and died in the city of São Paulo in 2008) (Figure 6 and 6a). He was a Brazilian mineralogist and petrologist and is generally considered Father of Brazilian Gemology. He did most of his studies at the University of São Paulo and obtained the Doctor of Science Degree in Mineralogy and Petrology in 1944. He occupied faculty positions at the University of São Paulo and the Unversity of Brasilia. He was director of the Graduate Program of the Instituto de Energia Atómica (presently Instituto de Pesquisas Energéticas e Nucleares-IPEN). Rui Franco was the author of four books and translated another five. The best known ones are Noções de Mineralogia e Geologia published in 1962 and Pedras Preciosas published in 1965.

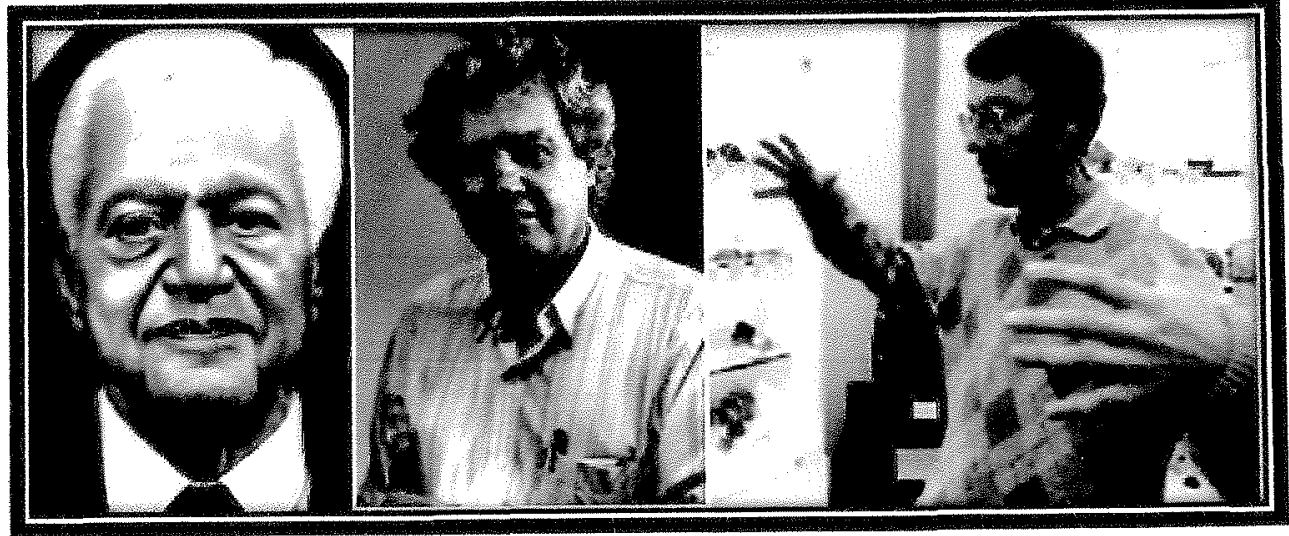

Figure 6 - Rui Ribeiro Franco ${ }^{2}$; Luiz Alberto Dias Menezes Filho ${ }^{2}$; Daniel Atencio ${ }^{19}$. 


\section{SOUTHERN BRAZILIAN JOURNAL OF CHEMISTRY}

SOUTH. BRAZ. J. CHEM. , Vol. 22, No. 22, 2014

P.C.P. Neves and L.G. Ionescu

Rui Ribeiro Franco was founder and president of the Brazilian Society of Geology and the Brazilian Association of Gemology and Mineralogy and member CNPq-Brazilian National Research Council. He received many prizes and awards. We cite the medal of Ordem Nacional do Mérito Cientúfico in 1995 and the Grã -Cruz da Ordem Nacional do Mérito Cientúfico in 2000.

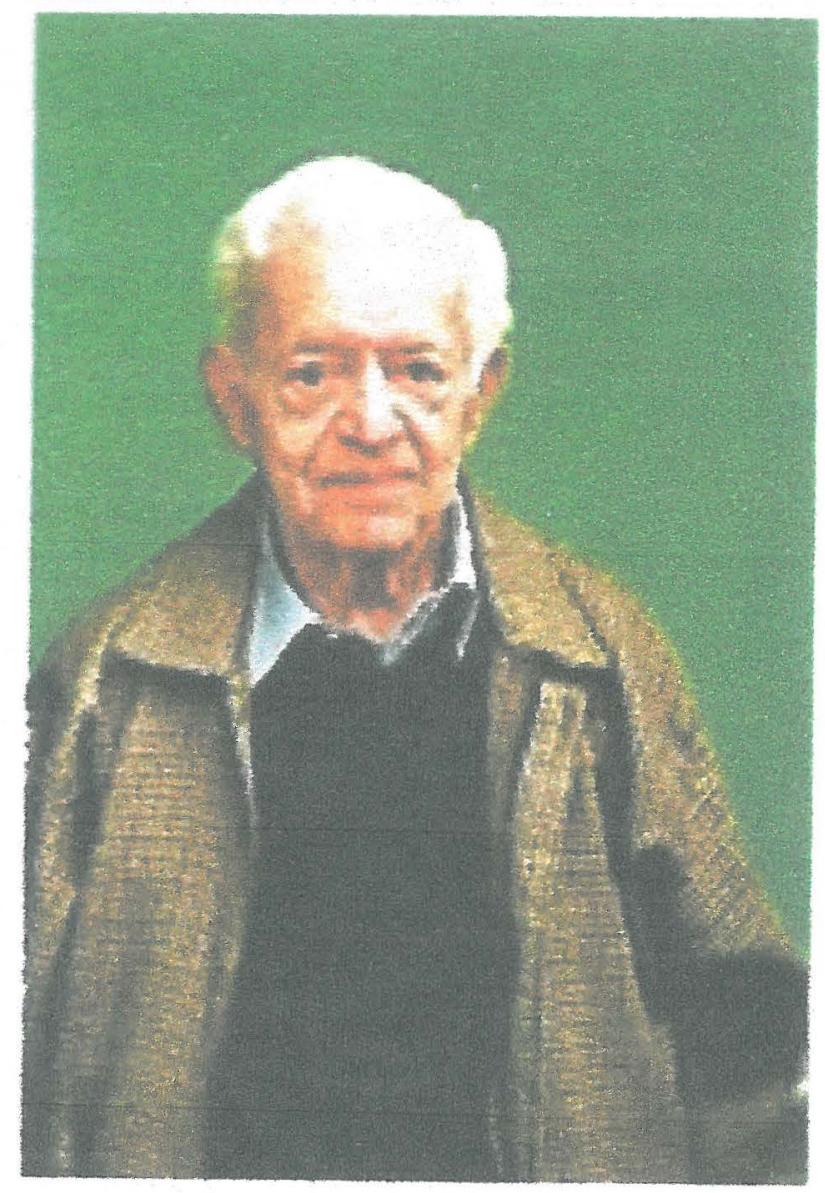

Rui Ribeiro Franco, Father of Brazilian Gemology

(1916-2008)

VISIT OUR SITE: http://www.sbjchem.he.com.br 


\section{SOUTHERN BRAZILIAN JOURNAL OF CHEMISTRY}

SOUTH. BRAZ. J. CHEM., Vol. 22, No. 22, 2014

In 2007, the type mineral from Brazill ruifrancoite, a phosphate from pegmatites of the Petroberil Mine, Sapucaia do Norte, Galileia, Minas Gerais and whose structure is given below was named in his honor.

$$
\left(\mathrm{Ca}_{2}\left(\square, \mathrm{Mn}^{2+}\right)_{2}\left(\mathrm{Fe}^{3+}, \mathrm{MgMn}^{2+}, \mathrm{Fe}^{2+}, \mathrm{Al}\right)_{4} \mathrm{Be}_{4}\left(\mathrm{PO}_{4}\right)_{6}(\mathrm{OH})_{4}\left(\mathrm{OH}, \mathrm{H}_{2} \mathrm{O}_{2} \cdot 4 \mathrm{H}_{2} \mathrm{O}\right)\right.
$$

22. Luiz Alberto Dias Menezes Filho (Born in São Paulo in 1950 and died in Belo Horizonte in 2014) (Figure 6). He was a mining engineer, a researcher and collector of minerals. He was one of the founders of the Brazilian Association of Mineralogy in 1965.

In 2008 the mineral menezesite, a niobate, $\mathrm{Ba}_{2} \mathrm{MgZr}_{4}\left(\mathrm{BaNb}_{12} \mathrm{O}_{42}\right) 12 \mathrm{H}_{2} \mathrm{O}$ was named in his honor. He also discovered in 2013 the type mineralls from Brazil pauloabibite $\left(\mathrm{NaNbO}_{3}\right)$ and almeidaite $\left(\mathrm{PbZn}_{2}(\mathrm{Mn}, \mathrm{Y}) \mathrm{Fe}^{3+}\right)_{18} \mathrm{O}_{37}(\mathrm{OH}, \mathrm{O})$.

23. Daniel Atencio (Born in São Caetano do Sul, São Paulo in 1959 (Figure 6). He is a Brazillan mineralogist, Professor at the University of São Paulo and discoverer of approximately 33 type minerals from Brazil, The type mineral from Brazil, atencioite $\left(\mathrm{Ca}_{2} \mathrm{Fe}^{2+}{ }_{3}\right) \mathrm{Mgg}_{3} \mathrm{Be}_{4}\left(\mathrm{PO}_{4}\right)_{6}(\mathrm{OH})_{4} \cdot 6 \mathrm{H}_{2} \mathrm{O}$, a phosphate was named in his honor. In 2014, the jourmal In the Mine awarded him the title of Immortal Geologist due to his scientific contributions. He is the author of three Books: Type Mineralogy of Brazil (2000), Enciclopédia dos Minerais do BrasilElementos Nativos e Halogenetos (2013) and Enciclopédia dos Minerais do BrasilSulfetos e Sulfossais (2014). He serves as Brazilian Represemtative on the Commission on New Minerals, and Mineral Names (CNMMN) and the Commission on New Minerals, Nomenclature and Classification (CNMNC) of the International Mineralogical Association. ${ }^{2,4}$ since 1990. 


\section{SOUTHERN BRAZILIAN, JOURNAL OF CHEMISTRY}

SOUTH. BRAZ. J. CHEM. , Vol. 22, No. 22, 2014

\section{P.C.P. Neves and L.G. Ionescu}

\section{REFERENCES}

1a. Neves, P.C.P. das; Atencio, D. "Enciclopédia dos Minerais do Brasil - Sulfetos e Sulfossais", Canoas, Editora da ULBRA, (2014), 431 pp.

1b. Neves, P.C.P. das, Atencio, D. and Ionescu, L.G., " A Brief History of Mineralogy in Brazil", South. Braz. J. Chem., 21(21), 109-127 (2013).

1c. Branco,de Moraes P., "Breve História da Mineralogia Brasileira", Serviço Geológico do Brasil, Companhia de Pesquisa de Recursos Minerais-CPRM, Canal Escola, p.1-8, 2013, hrtp://www.cprm.gov.br/publique/cgl/crillua.exe/ sys /start.htm?infoid=2566\&SID=129, acessado 27.09.2013.

1d. Neves, P.C. das;Branco,de Moraes P. and Matioli, P.A., "The Pércio de Moraes Branco Collection of Rare Minerals of the Universidade Luterana do Brasil", South. Braz. J. Chem., 5(5), 51-66 (1997).

1e. Ionescu, L.G. and Neves, P.C.P. das, "Chemical Elements, Alloys and Minerals Occuring in Meteorites", South. Braz. J. Chem., 9(10),47-62 (2001).

1f. Franco, R.R., "A Mineralogia e Petrologia no Brasil", in História das Ciências no Brasil, M.Guimarães Ferri and S. Motoyama, Eds., Vol. 3. p.142, 1981, Editora EDUSP, São Paulo, 1981.

1g. Leonardos, O.H., "A Mineralogia e Petrologia no Brasil", in As Ciências no Brasil, Fernando Azevedo, Ed.,Vol. 1, p.265-313, 1955, Edição Melhoramentos, São Paulo, 1955.

2. Cornejo, C.; Bartorelli, A. "Minerais e Pedras Preciosas do Brasil". São Paulo: Solaris, (2010), 704p.

3. Araújo, S. C. A história (1576) de Pero de Magalhães Gândavo: notas para uma releitura desde a retórica e a gramática. Locus revista de História. 15(2), 71-83 (2009).

4. Neves, P. C. P. das; Atencio, D. "Enciclopédia dos Minerais do Brasil Elementos Nativos e Halogenetos". Canoas: Editora da ULBRA, (2013), 255p. 5. Figuerôa, S. M. F. Resenha - Minerais e Pedras Preciosas do Brasil. Terrae Didatica, 6(2), 123-124 (2010).

6. Atencio, D. "Type Mineralogy of Brazil". São Paulo: Museu de Geociências USP, (2000), 114p.

7. Bateman, A. M. "Yacimientos minerales de rendimiento econômico" Barcelona: Ediciones Omega, (1968), 975p.

8. Pinsky, J. "A escravidão no Brasill". São Paulo: Contexto, (2010), 90p. 9. Bueno, E. "Brasil: uma história - a incrivel saga de um país" São Paulo: Ática, (2003), 447p.

\section{SITES CONSULTED}

10.http://jchistorybrasil.webnode.com.br/album/galeria $\% 20 \mathrm{de} \% 20$ fotos $\% 3 \mathrm{~A} \% 20 \mathrm{i}$ greja, $\% 20$ educa $\% \mathrm{C} 3 \% \mathrm{~A} 7 \% \mathrm{C} 3 \% \mathrm{A30} \% 20 \mathrm{e} \% 20$ cultura $\% 20$ no $\% 20 \mathrm{brasil} \% 20$ colo nial/pero\%20de $\% 20$ magalh $\%$ C3\%A3es\%20g\%C3\%A2ndavo-jpg/, consultado em 15.12.2014.

11.http://educaterra.terra.com.br/voltaire/500br/tratado_descritivo.htm, consultado em 15.12.2014. 


\section{SOUTHERN BRAZILIAN JOURNAL OF CHEMISTRY}

SOUTH. BRAZ. J. CHEM. , Vol. 22, No. 22, 2014

12. http://www.redevampyrica.com/home/os-misterios-do-casarao-afonso-sardinha/ consultado em 15.12.2014.

13. http://de.wikipedia.org/wiki/Dietrich_Ludwig_Gustav_Karsten, consultado em 16.12.2014.

14. http://de.wikipedia.org/wiki/Johann_Baptist_von_Spix, consultado em 17.12.2014.

15. http://www.brasil.gov.br/old/copy_of_imagens/sobre/historia/personagenshistoricos/jose-bonifacio-de-andrada-e-silva-1763-1838/jose-bonifacio-de-andradae-silva-0-patriarca-da-independencia/image_view_fullscreen, consultado em 17.12.2014.

16. http://pt.wikipedia.org/wiki/Carl_Friedrich_Philipp_von_Martius, consultado em 18.12.2014.

17. http://www.npg.org.uk/collections/search/portraitlist.php?set=424\&displaystyl $e=$ thumb\&wPage $=11$, consultado em 19.12.2014.

18. https://www.ufmg.br/diversa/11/artigo4.html, consultado em 19.12.2014.

19. http://www.usp.br/jorusp/arquivo/2005/jusp735/pag08.htm, consultado em

21.12.2014.

20. http://www.revistas.usp.br/bigusp/article/viewFile/45336/48948, consultado em 21.12.2014.

The pictures of Augustin Alexis Damour, Claude-Henri Gorceix, Dom Pedro Augusto Maria Miguel Gabriel Rafael Gonzaga de Saxe-Coburgo-Gotha e Bragança, Eugen Hussak, Joaquim Cândido da Costa Sena, Orville Adelbert Derby, Rui Ribeiro Franco, Viktor Leinz and Wilhelm Ludwig von Eschwege, have as source: Solaris Cultural Works, Cornejo and Bartorelli, 2010, in drawings of Mei Zijian (with permission).

The image of Luiz Alberto Dias de Menezes Filho, has as source: Solaris Edições Culturais, Cornejo and Bartorelli, 2010, photograph by Andrea Bartorelli (with permission).

The large colored image of José Bonifácio is from a painting by Benedito Calixto and the colored photograph of Rui Ribeiro Franco was taken by Andrea Bartorelli.

VISIT OUR SITE: http://www.sbjchem.he.com.br

The SOUTHERN BRAZILIAN JOURNAL OF CHEMISTRY (ISSN: 2674-6891; 0104-5431) is an open-access journal since 1993. Journal DOI: 10.48141/SBJCHEM. http://www.sbjchem.com.

This text was introduced in this file in 2021 for compliance reasons.

(C) The Author(s)

OPEN ACCESS. This article is licensed under a Creative Commons Attribution 4.0 (CC BY 4.0) International License, which permits use, sharing, adaptation , distribution , and reproduction in any medium or format, as long as you give appropriate credit to the original author (s) and the source, provide a link to the Creative Commons license, and indicate if changes were made. The images or other third-party material in this article are included in the article's Creative Commons license unless indicated otherwise in a credit line to the material. If material is not included in the article's Creative Commons license and your intended use is not permitted by statutory regulation or exceeds the permitted use, you will need to obtain permission directly from the copyright holder. To view a copy of this license, visit http://creativecommons.org/ licenses/by/4.0/. 